\title{
Studies of the occupational exposure of Malaysian plantation workers to paraquat
}

\author{
G CHESTER ${ }^{1}$ AND B H WOOLLEN ${ }^{2}$
}

From the Acute Toxicity Section ${ }^{1}$ and the Analytical Biochemistry Section, ${ }^{2}$ Imperial Chemical Industries Ltd, Central Toxicology Laboratory, Alderley Park, Nr Macclesfield, Cheshire SKIO 4TJ, UK

ABSTRACT Studies carried out on the occupational exposure to paraquat of plantation workers in Malaysia comprised quantitative estimates of dermal and respiratory exposure of knapsack spray operators, carriers, and rubber tappers operating under their normal working conditions. Spray operators have been shown to be dermally exposed to paraquat by walking through recently sprayed vegetation and into their own spray, regular adjustment and unblocking of spray nozzles and leakage, and overfilling of knapsack spray tanks. Carriers also received measurable dermal exposure from walking through recently sprayed vegetation and accidental spillage when carrying and loading. The infrequent and negligible dermal exposure of tappers resulted from walking through recently sprayed vegetation. Determinations of the total airborne paraquat concentrations in the breathing zone show that spray operators and carriers are exposed to an order of $1 \%$ or less of the current TLV for respirable paraquat. No paraquat was detected in the breathing zones of tappers working in simultaneously sprayed blocks. The calculated ranges of dermal and respiratory exposures, when compared with published data on both the exposure to, and the toxicity of, paraquat, indicate that there should be no toxicological risk to any of the three groups studied as a result of using paraquat.

Spray worker exposure to paraquat* has been the subject of several investigations. ${ }^{1-3}$ Swan $^{1}$ identified the exposure of knapsack spray operators as representing the highest exposure to paraquat in agricultural practice, and he investigated the extent of systemic absorption of paraquat during spraying operations on Malaysian rubber plantations. Paraquat is sprayed for weed control on these plantations for 10 months of the year by gangs of operators working six to seven hours a day, six days a week. For these reasons these same plantations were selected for extensive investigations of occupational dermal and respiratory exposure to paraquat, in association with a health survey of spray operators and other estate workers. ${ }^{4}$

The selected locations for the investigations were

*As Gramoxone agricultural concentrate containing $20 \%$ paraquat as the dichloride, equivalent to $14.5 \%$ paraquat cation. All references to paraquat in the text and tables refer to the cation.

Requests for reprints to $\mathrm{G}$ Chester.

Received 12 January 1981

Accepted 30 March 1981 the plantations of Dunlop Estates (Bhd) in Malaysia, and these investigations took place during September and October 1978 and May and June 1979.

The objective was to examine the potential dermal and respiratory exposure of knapsack spray operators, pesticide formulation carriers, and rubber tappers to paraquat during their normal working regimens. The study was undertaken in two parts: (1) an evaluation of the potential dermal and respiratory exposure of workers using methods similar to those described in the WHO Standard Protocol, ${ }^{5}$ and (2) additional measurements of a similar nature on spray operators and a more extensive evaluation of tapper dermal exposure, including tappers working in simultaneously sprayed areas.

\section{Method}

SURVEY GROUPS

Study 1 comprised occupational exposure surveys on three types of worker, and were conducted on four Dunlop estates (table 1). These estates were selected so that possible variations in terrain, crop, and work procedure could be studied. Study 2 comprised 
Table 1 Study 1: survey details

\begin{tabular}{|c|c|c|c|}
\hline \multirow[t]{2}{*}{ Dunlop Estate } & \multicolumn{3}{|c|}{ No and sex of workers per survey group } \\
\hline & Spray operators & Carriers & Rubber tappers \\
\hline $\begin{array}{l}\text { Regent } \\
\text { Jasin Lallang } \\
\text { Gomali } \\
\text { Segamat } \\
\text { Regent* }\end{array}$ & $\begin{array}{l}4 \text { men } \\
4 \text { women } \\
4 \text { men } \\
4 \text { men } \\
3 \text { men }\end{array}$ & $\begin{array}{l}1 \text { woman } \\
1 \text { man } \\
2 \text { men } \\
2 \text { women } \\
1 \text { woman }\end{array}$ & 4 men \\
\hline
\end{tabular}

*Two surveys were carried out on Regent Estate owing to its close proximity to the monitoring teams' accommodation. To use alternative estates, other than those already studied, would have been impracticable.

Table 2 Study 2: survey details

\begin{tabular}{|c|c|c|c|c|}
\hline Survey title & $\begin{array}{l}\text { No of } \\
\text { surveys }\end{array}$ & \multicolumn{3}{|c|}{$\begin{array}{l}\text { No and sex of workers per } \\
\text { survey }\end{array}$} \\
\hline $\begin{array}{l}\text { Dermal exposure of } \\
\text { tappers } \\
\text { Dermal and respiratory } \\
\text { exposure of tappers in } \\
\text { simultaneously sprayed } \\
\text { areas } \\
\text { Dermal and respiratory } \\
\text { exposure of spray } \\
\text { operators }\end{array}$ & 18 & $\begin{array}{l}\text { Survey } 1 \\
2 \text { women } \\
3 \text { men }\end{array}$ & 10 men & $\begin{array}{l}\text { Survey } 2 \\
5 \text { men }\end{array}$ \\
\hline
\end{tabular}

more extensive surveys conducted on Dunlop Sagil Estate (table 2).

\section{Study procedures}

\section{STUDY 1}

Five groups of spray operators and carriers were randomly selected from four Dunlop estates and their dermal and respiratory exposure to paraquat measured during a typical working day. The dermal exposure of a single, randomly selected group of tappers was monitored on a single occasion.

Dermal and respiratory exposures to paraquat were estimated using the procedure described in the WHO Standard Protocol ${ }^{5}$ with the following modifications:

(1) Dermal exposure pads consisted of polyethylene-backed Whatman Grade 542 filter papers, with an exposed filter surface area of roughly $80 \mathrm{~cm}^{2}$.

(2) These pads were applied to skin (if directly exposed) or clothing as follows: left arm-(a) midforearm (upper surface), (b) mid-upper arm; left leg - (c) mid-lower leg, or if boot worn, below knee $(d)$ mid-thigh; trunk- $(e)$ sternum beneath clothing $(f)$ upper chest over shirt close to "v" of neck; $(g)$ lower back, beneath knapsack sprayer (spray operators only); head- $(h)$ forehead.

(3) On completion of spraying, whole pads were removed and stored individually in sealed labelled polyethylene bags and were subsequently returned to Britain for analysis of paraquat content.
(4) Respiratory exposure was determined using Rotheroe-Mitchell* L2SF personal air samplers, operated at a flow rate of $21 \mathrm{air} / \mathrm{min}$ for the entire duration of each survey. The instrument flow rates were calibrated before and after each survey using a GAP $\dagger$ flow-meter with a range of 0-5 1 air $/ \mathrm{min}$. Total paraquat aerosol (all droplets irrespective of size) was collected on $2.5 \mathrm{~cm}$ diameter filter papers, Whatman No 1 or 542 , located in sampling heads in the breathing zone. These filters have collection efficiencies of $100 \%$ for particle sizes down to $2 \mu \mathrm{m}$ diameter.

(5) Urine samples were collected from all survey participants immediately after completion of spraying. Each worker was instructed to exercise care in giving the samples to avoid accidental contamination of the sample with paraquat-for example, from contaminated hands or clothing. All samples were stored individually in labelled polyethylene vials containing azide as preservative and maintained at $4^{\circ} \mathrm{C}$ pending analysis of paraquat content.

\section{STUDY 2}

(1) Dermal exposure of rubber tappers-A group of 10 tappers was randomly selected from the working tapper population on Sagil Estate, and their dermal exposure to paraquat was monitored over 18 consecutive working days. The procedure for this was exactly as previously described, with exposure pads located on skin or beneath clothing as follows: (a) forehead; (b) "v" of neck; (c) sternum beneath shirt; $(d)$ mid-left forearm; $(e)$ mid-left thigh; and $(f)$ mid-left lower leg.

(2) Dermal and respiratory exposure of tappers in sprayed areas-A group of five tappers was surveyed in a block simultaneously sprayed with a paraquatcontaining herbicide formulation. Dermal exposure was estimated as previously described. In addition, the dermal exposure of the legs beneath clothing was estimated using a Tubigrip $\ddagger$ or Macrom Stockinette tubular support bandage. $\S$ This was located adjacent to the skin from the top of the right thigh to the ankle. All pads and bandages were removed on completion of tapping and stored as previously described.

Respiratory exposure was determined for each tapper in the second of the two surveys as previously described.

*Rotheroe and Mitchell Ltd, 14 Aintree Road, Greenford, Middlesex UB6 7LJ.

†G A Platon Ltd, Flow Control, Wella Road, Basingstoke, Hampshire.

$\ddagger$ Manufactured by: Seton, Tubiton House, Oldham OL1 3HS.

§Manufactured by: McCarthys Surgical Ltd, Selinas Lane, Dagenham, Essex RM8 1QD. 
(3) Dermal and respiratory exposure of spray operators-From the first study, the dermal exposure of the legs and hands had been identified as being potentially important. Therefore, an attempt was made to assess more realistically the exposure of these body areas by using a better method than was previously used. Tubigrip bandages were used to estimate the penetration of paraquat through clothing to the underlying skin of the legs. They were located on the left legs of five spray operators in surveys 1 and 2 and on both legs in surveys 3 and 4 .

In this second series of measurements the dermal exposure of the hands was estimated using white cotton gloves worn throughout the work period. Removal and storage of Tubigrip and gloves were as previously described.

Respiratory exposure was determined as previously described

\section{OPERATIONAL DETAILS}

All relevant operational details were recorded during both studies and included the following: location, administration of spraying, duration of spraying and exposure, weed type, terrain, herbicide formulation, concentration of paraquat, application rate, spray equipment, tank capacity, nozzle type, washing facilities (if any), and protective clothing (if any).

\section{MICROMETEOROLOGICAL MEASUREMENTS}

Air temperature and relative humidity were recorded on the day of each survey during study 1 using a whirling hygrometer (Casella*). During the second study most measurements were provided by the Sagil Estate meteorological station. Windspeed was measured using a wind meter (Dwyer $\dagger$ ). Cloud cover and incidence of rain were also recorded.

\section{DETERMINATION OF PARAQUAT}

Analysis of filter paper, Tubigrip, and glove samples was carried out using a modified version of the colorimetric procedure of Calderbank and Yuen. ${ }^{6}$ Paraquat was extracted from the samples by shaking with saturated ammonium chloride. The extract was mixed with a solution of sodium dithionite, and the absorbance was measured at $600 \mathrm{~nm}$. Paraquat was determined in urine and on air sampler filter papers by radioimmunoassay. ${ }^{7}$ Appropriate corrections were made for the extraction efficiency of paraquat from different sampling media.

\section{CALCULATIONS}

The dermal exposure data were adjusted to uniform

*C F Casella \& Co Ltd, Regent House, Britania Walk, London NL 7ND.

†Dwyer Instruments Inc, Michigan City, Indiana 46360, USA. time and extrapolated from mg paraquat per $25 \mathrm{~cm}^{2}$ filter to $\mathrm{mg}$ paraquat per body part per hour to calculate the dermal exposure of individual body parts. The body part surface areas given in the WHO Standard Protocol ${ }^{5}$ were used for this extrapolation. As these areas have been derived for a $70 \mathrm{~kg}$ Caucasian they have been reduced proportionally to take into consideration the lower mean body weight, height, ${ }^{4}$ and total surface area of South-east Asians. In determining the latter a Documenta Geigy8 height-area-weight nomogram was used. The mean body weights and heights used were: weight : $\operatorname{man}-$ $60 \mathrm{~kg}$; woman-55 kg and height: $\operatorname{man}-1.625 \mathrm{~m}$; woman $-1.511 \mathrm{~m}$. Using these data, the following body surface areas were derived: $\operatorname{man}-1.65 \mathrm{~m}^{2}$; woman $-1.5 \mathrm{~m}^{2}$.

In the case of Tubigrip and glove samples no area extrapolation was necessary except for the leg exposure data of spray operators, in surveys 1 and 2 of study 2 , in which only the left legs were sampled.

The respiratory exposure data were adjusted to $\mathrm{mg}$ paraquat per $\mathrm{m}^{3}$ air using the sampling rate and durations, and hence total volume of air sampled.

The percentage toxic dose per hour was calculated for each worker who participated in the first study according to the method of Durham and Wolfe. ${ }^{9}$ It was not possible to include the respiratory exposure data in this calculation as respiratory minute volumes for South-east Asians are not accurately known. The dermal LD50 value used in the derivation of the percentage dose was $91 \mathrm{mg}$ paraquat cation $/ \mathrm{kg}$ obtained for a paraquat concentrate formulation in rats. ${ }^{10}$ This value was used because the formulation tested was identical to the paraquat formulation manufactured and used in Malaysia. The choice of the rat dermal LD50 value in this calculation is governed by WHO Standard Protocol ${ }^{5}$ requirements based on the original derivation of the equation by Durham and Wolfe. ${ }^{9}$ The equation attempts to relate an exposure per one hour in man to an exposure per 24 hours in rats under occlusive dressings and, as such, is not the ideal comparison to make. It is, however, generally accepted and will allow comparisons to be made with other studies of exposure to paraquat or different pesticides.

\section{Results}

OPERATIONAL DETAILS

Paraquat was usually sprayed in combination with monosodium methane-arsenate, diuron, or aminotriazole. The durations of spraying were variable (135-254 $\mathrm{min})$ and reflected the time taken to spray the areas allotted to the operators on the occasions of the surveys. A rainstorm was responsible for the relatively short spraying time of 135 minutes. The 
Table 3 Dermal exposure of spray operators. Study 1

\begin{tabular}{|c|c|c|c|c|c|c|c|c|c|}
\hline \multirow{3}{*}{$\begin{array}{l}\text { Dunlop } \\
\text { estate }\end{array}$} & \multirow{3}{*}{$\begin{array}{l}\text { Worker } \\
\text { and sex }\end{array}$} & \multirow{3}{*}{$\begin{array}{l}\text { Sampling } \\
\text { duration } \\
\text { (mins) }\end{array}$} & \multicolumn{7}{|c|}{ Dermal exposure (mg paraquat/h) } \\
\hline & & & \multicolumn{5}{|c|}{ Unclothed body parts } & \multicolumn{2}{|c|}{ Clothed body parts } \\
\hline & & & Head & "V" of neck & Shoulders & Hands & Forearms & Forearms & Upper arms \\
\hline \multirow{4}{*}{ Regent } & $1 \mathbf{M}$ & 135 & ND & NI) & ND & 0.53 & 0.79 & & ND \\
\hline & $2 \mathrm{M}$ & 135 & 0.36 & NI) & 0.1 & ND & & ND & ND \\
\hline & $3 \mathbf{M}$ & 135 & 0.79 & 0.04 & $0 \cdot 21$ & 0.22 & & 0.33 & 0.95 \\
\hline & $4 M$ & 135 & ND & 0.05 & ND & $2 \cdot 53$ & & $3 \cdot 8$ & 0.45 \\
\hline Jasin & $1 \mathrm{~F}$ & 254 & ND & 0.02 & ND & 0.11 & $0 \cdot 16$ & & ND \\
\hline \multirow[t]{3}{*}{ Ballang } & $2 \mathrm{~F}$ & 254 & ND & ND & ND & 1.03 & $1 \cdot 51$ & & ND \\
\hline & $3 \mathrm{~F}$ & 254 & ND & ND & ND & 0.08 & & 0.11 & ND \\
\hline & $4 \mathrm{~F}$ & 254 & ND & ND & ND & ND & & ND & ND \\
\hline \multirow[t]{4}{*}{ Comali } & $1 \mathrm{M}$ & 140 & ND & $0 \cdot 19$ & ND & $2 \cdot 25$ & & $3 \cdot 36$ & 1.56 \\
\hline & $2 \mathrm{M}$ & 140 & ND & ND & ND & 0.3 & & 0.45 & ND \\
\hline & $3 \mathbf{M}$ & 140 & ND & 0.06 & ND & $4 \cdot 6$ & & 6.91 & $1 \cdot 76$ \\
\hline & $4 \mathrm{M}$ & 140 & ND & ND & ND & $0 \cdot 12$ & & $0 \cdot 19$ & $6 \cdot 34$ \\
\hline \multirow[t]{4}{*}{ Segamat } & $1 \mathrm{M}$ & 160 & ND & 0.03 & ND & $2 \cdot 24$ & & $3 \cdot 35$ & 0.21 \\
\hline & $2 \mathrm{M}$ & 160 & ND & ND & ND & ND & & ND & ND \\
\hline & $3 \mathbf{M}$ & 160 & ND & ND & ND & 0.22 & 0.33 & & 0.7 \\
\hline & $4 M$ & 160 & ND & 0.04 & ND & $0 \cdot 37$ & 0.56 & & 0.29 \\
\hline \multirow[t]{3}{*}{ Regent } & $1 \mathrm{M}$ & 225 & ND & 0.02 & ND & 1.0 & $1 \cdot 50$ & & 0.21 \\
\hline & $2 \mathrm{M}$ & 225 & 0.67 & 0.56 & $0 \cdot 17$ & $4 \cdot 4$ & $6 \cdot 56$ & & $5 \cdot 9$ \\
\hline & $3 \mathbf{M}$ & 225 & $1 \cdot 77$ & 0.63 & 0.47 & $4 \cdot 74$ & & $7 \cdot 09$ & 5.04 \\
\hline $\begin{array}{l}\text { Mean } \\
\text { SD }\end{array}$ & & & & & & & & & \\
\hline
\end{tabular}

ND $=$ None detected.

Lower limit of detection $10 \mu \mathrm{g} /$ filter.

SD $=$ Standard deviation.

durations of exposure were usually identical to the spraying times, and are given with each table of dermal exposure values. In study 1 it was necessary to remove lower leg pads and, additionally in Gomali survey, thigh pads after 30,40 , or 55 minutes spraying time, owing to wetting of the pads with a combination of spray and dew to the point of saturation. This problem was unique to the leg pads. Although the trouser material also became wet, spray "run-off" did not occur because of the thickness of the material relative to that of the pads. The dilution of paraquat concentrate was one fluid ounce to one gallon of water (equivalent to $6.3 \mathrm{ml}$ concentrate to 1 litre of water), and the measured paraquat concentration varied from 0.1 to $0.2 \%$. The standard spray equipment used was a knapsack sprayer of three gallons capacity, and the nozzle either a polijet, a solid cone, or a fanjet. The application rates used ranged from 135 to $169 \mathrm{l} / \mathrm{ha}$. The crops in which herbicide spraying for weed control took place on the occasions of the surveys were rubber, cocoa, or oil palm, and considerable variation in weed height and terrain was noted.

On the estates visited during the first study it was standard practice at the central chemical store to dilute the herbicide concentrates with water in a transportable tank, which was then towed out to the block in which spraying was to take place. On Sagil Estate (the location for all surveys of the second study) it was standard practice to dilute the concentrates in the field using water dispensed from a transportable tank. The function of the carrier on all estates was to dispense formulation or water into buckets and carry them to the sprayers, where dilution of the concentrates and loading took place.

MICROMETEOROLOGICAL MEASUREMENTS

The mean air temperature measured during the five days of the first study was $26^{\circ} \mathrm{C}\left(25-28^{\circ} \mathrm{C}\right)$. Mean relative humidity was $86 \%(84-88 \%)$. All recorded windspeeds were zero.

Air temperature during the four weeks of the second study varied from a mean of $23.5^{\circ} \mathrm{C}(21$ $\left.26.5^{\circ} \mathrm{C}\right)$ at 0700 to $31^{\circ} \mathrm{C}\left(28-35^{\circ} \mathrm{C}\right)$ at 1500 . Relative humidity likewise varied from $95 \%(90-100 \%)$ to $72 \%(54-84 \%)$. Mean rainfall was $7 \mathrm{~mm}(0-57.5 \mathrm{~mm})$ over the same period. All recorded wind speeds were zero.

DERMAL EXPOSURE

Calculated dermal exposures for spray operators, carriers, and tappers monitored during the first study are presented in tables 3 and 4 . Individual body parts have been separated into two categories according to whether they were clothed or not. Two estimates of total exposure are given. The first is a summation of individual exposures of unclothed areas-that is, those body parts such as hands and head not normally covered-which is the recommended procedure given in the WHO Standard Protocol. ${ }^{5}$ The second is a summation of unclothed and clothed body areas. Similarly, two estimates of dermal dose are given. The distinction has been drawn because the former interpretation assumes that the clothing 


\begin{tabular}{|c|c|c|c|c|c|c|c|c|}
\hline \multirow[b]{3}{*}{ Sternum } & \multirow[b]{3}{*}{ Buttocks } & \multirow[b]{3}{*}{ Thighs } & \multirow[b]{3}{*}{ Lower legs } & \multirow{3}{*}{$\begin{array}{l}\text { Direct exposure } \\
\text { of unclothed body } \\
\text { parts }(\mathrm{mg} / \mathrm{h})\end{array}$} & \multirow{3}{*}{$\begin{array}{l}\text { Total exposure } \\
v(\text { potential }) \\
(\mathrm{mg} / \mathrm{h})\end{array}$} & \multicolumn{2}{|c|}{$\begin{array}{l}\text { Dermal dose } \\
(\mathrm{mg} / \mathrm{kg} / \mathrm{h})\end{array}$} & \multirow{3}{*}{$\begin{array}{l}\text { Percentage toxic } \\
\text { dose } \\
\text { (direct exposed) } \\
\text { (percentage/h) }\end{array}$} \\
\hline & & & & & & \multirow{2}{*}{$\begin{array}{l}\text { Directly } \\
\text { exposed }\end{array}$} & \multirow{2}{*}{$\begin{array}{l}\text { Total } \\
\text { potential }\end{array}$} & \\
\hline & & & & & & & & \\
\hline ND & $4 \cdot 4$ & $26 \cdot 8$ & $55 \cdot 3$ & $1 \cdot 3$ & $87 \cdot 8$ & 0.02 & $1 \cdot 5$ & 0.02 \\
\hline ND & 6.0 & $26 \cdot 2$ & $19 \cdot 9$ & 0.5 & $53 \cdot 1$ & $8 \times 10^{-3}$ & 0.9 & $9.2 \times 10^{-3}$ \\
\hline ND & $9 \cdot 7$ & $75 \cdot 8$ & $27 \cdot 0$ & $1 \cdot 3$ & 115.0 & 0.02 & 1.9 & 0.03 \\
\hline ND & $2 \cdot 2$ & $72 \cdot 7$ & $45 \cdot 2$ & $2 \cdot 6$ & 126.9 & 0.04 & $2 \cdot 1$ & 0.05 \\
\hline ND & $2 \cdot 9$ & 1.45 & $17 \cdot 5$ & $0 \cdot 3$ & $22 \cdot 1$ & $5 \times 10^{-3}$ & 0.4 & $6.3 \times 10^{-3}$ \\
\hline ND & $0 \cdot 36$ & $11 \cdot 85$ & $16 \cdot 5$ & $2 \cdot 5$ & $31 \cdot 3$ & 0.05 & 0.6 & 0.06 \\
\hline ND & 0.21 & 8.90 & $14 \cdot 8$ & 0.1 & $24 \cdot 1$ & $2 \times 10^{-3}$ & 0.4 & $2 \times 10^{-3}$ \\
\hline ND & ND & $18 \cdot 58$ & $21 \cdot 6$ & ND & $40 \cdot 2$ & 0 & 0.7 & 0 \\
\hline ND & $1 \cdot 55$ & $24 \cdot 72$ & No pad & $2 \cdot 4$ & 33.6 & 0.04 & 0.6 & 0.05 \\
\hline ND & 0.6 & $23 \cdot 1$ & $145 \cdot 29$ & 0.3 & $169 \cdot 8$ & $5 \times 10^{-3}$ & $2 \cdot 8$ & $6 \times 10^{-3}$ \\
\hline ND & $0 \cdot 18$ & $70 \cdot 4$ & $17 \cdot 82$ & $4 \cdot 7$ & $101 \cdot 7$ & 0.08 & $1 \cdot 7$ & $0 \cdot 1$ \\
\hline ND & $8 \cdot 86$ & $11 \cdot 29$ & $39 \cdot 75$ & $0 \cdot 1$ & $66 \cdot 6$ & $2 \times 10^{-3}$ & $1 \cdot 1$ & $2 \times 10^{-3}$ \\
\hline ND & 0.24 & $14 \cdot 04$ & $21 \cdot 28$ & $2 \cdot 3$ & $41 \cdot 4$ & 0.04 & 0.7 & 0.05 \\
\hline ND & No pad & $3 \cdot 51$ & $8 \cdot 54$ & ND & $12 \cdot 1$ & 0 & $0 \cdot 2$ & 0 \\
\hline ND & 6.04 & $11 \cdot 79$ & $29 \cdot 32$ & 0.6 & $48 \cdot 4$ & $9 \times 10^{-3}$ & 0.8 & 0.01 \\
\hline ND & 0.55 & $51 \cdot 41$ & $42 \cdot 72$ & 1.0 & $95 \cdot 9$ & 0.02 & $1 \cdot 6$ & 0.02 \\
\hline ND & 0.71 & $23 \cdot 40$ & $24 \cdot 12$ & $2 \cdot 5$ & $51 \cdot 0$ & 0.04 & 0.9 & 0.05 \\
\hline ND & ND & 30.93 & $21 \cdot 0$ & $12 \cdot 4$ & $70 \cdot 2$ & $0 \cdot 2$ & $1 \cdot 1$ & $0 \cdot 25$ \\
\hline \multirow[t]{3}{*}{ ND } & ND & $17 \cdot 05$ & $26 \cdot 47$ & $7 \cdot 6$ & 63.6 & $0 \cdot 1$ & $1 \cdot 1$ & $0 \cdot 16$ \\
\hline & & & & $2 \cdot 2$ & 66.0 & 0.04 & $1 \cdot 1$ & 0.05 \\
\hline & & & & $3 \cdot 2$ & $41 \cdot 1$ & 0.05 & $0 \cdot 7$ & 0.06 \\
\hline
\end{tabular}

worn by a spray worker affords him a measure of protection from dermal contamination with sprayed pesticide, whereas the latter allows estimation of the total potential exposure.

There were large differences between unclothed total and overall total exposure for each spray operator (table 3 ). The mean unclothed exposure was $2.2 \mathrm{mg}$ paraquat/h of spraying with individual variation from zero to $12.6 \mathrm{mg}$ paraquat $/ \mathrm{h}$. The mean value of $2.2 \mathrm{mg} / \mathrm{h}$ is equivalent to a dermal dose of $0.04 \mathrm{mg} / \mathrm{kg} / \mathrm{h}$. The highest individual direct dermal exposure of $12.6 \mathrm{mg} / \mathrm{h}$ is equivalent to $0 \cdot 2$ $\mathrm{mg} / \mathrm{kg} / \mathrm{h}$. The mean overall total exposure was $66 \mathrm{mg}$ paraquat $/ \mathrm{h}$, with individual variation from $12 \cdot 1 \mathrm{mg} / \mathrm{h}$

Table 4 Dermal exposure of carriers and tappers. Study 1

\begin{tabular}{|c|c|c|c|c|c|c|c|c|c|c|c|c|c|c|c|}
\hline \multirow{3}{*}{$\begin{array}{l}\text { Dunlop } \\
\text { estate }\end{array}$} & \multirow{3}{*}{$\begin{array}{c}\text { Worker Sampling } \\
\text { and sex duration } \\
\text { (mins) }\end{array}$} & \multicolumn{11}{|c|}{ Dermal exposure (mg paraquat/h) } & \multirow{2}{*}{\multicolumn{2}{|c|}{$\begin{array}{l}\text { Dermal dose } \\
(\mathrm{mg} / \mathrm{kg} / \mathrm{h})\end{array}$}} & \multirow{3}{*}{$\begin{array}{l}\text { Percentage } \\
\text { toxic dose } \\
\text { (direct } \\
\text { exposed) } \\
\text { (percentage } \\
\text { (h) }\end{array}$} \\
\hline & & \multicolumn{4}{|c|}{ Unclothed body parts } & \multicolumn{5}{|c|}{ Clothed body parts } & \multirow{2}{*}{$\begin{array}{l}\text { Direct } \\
\text { exposure of } \\
\text { unclothed } \\
\text { body parts } \\
(\mathrm{mg} / \mathrm{h})\end{array}$} & \multirow{2}{*}{$\begin{array}{l}\text { Total } \\
\text { exposure } \\
\text { (potential) } \\
(\mathrm{mg} / \mathrm{h})\end{array}$} & & & \\
\hline & & Head & $\begin{array}{l}\text { " } V \text { ", } \\
\text { of } \\
\text { neck }\end{array}$ & Shoulders & Hands & Forearms & Sternum & $\begin{array}{l}\text { Upper } \\
\text { arms }\end{array}$ & Thighs 1 & $\begin{array}{l}\text { Lower } \\
\text { legs }\end{array}$ & & & $\begin{array}{l}\text { Directly } \\
\text { exposed }\end{array}$ & $\begin{array}{l}\text { Total } \\
\text { potential }\end{array}$ & \\
\hline $\begin{array}{l}\text { Regent } \\
\text { Jasin }\end{array}$ & 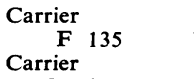 & ND & ND & ND & ND & ND & ND & ND & 0.51 & $1 \cdot 83$ & ND & $2 \cdot 3$ & 0 & 0.04 & 0 \\
\hline $\begin{array}{l}\text { Lallang } \\
\text { Gomali }\end{array}$ & $\underset{\text { Carrier }}{\text { M }} 254$ & $0 \cdot 1$ & ND & ND & ND & ND & ND & ND & ND & ND & $0 \cdot 1$ & ND & \multicolumn{3}{|c|}{$1.7 \times 10^{-3} 1.7 \times 10^{-3} 2 \times 10^{-3}$} \\
\hline & $\begin{array}{l}1 \mathrm{M} 140 \\
\text { Carrier }\end{array}$ & ND & ND & ND & ND & ND & ND & ND & ND & ND & ND & ND & 0 & 0 & 0 \\
\hline Segamat & $\underset{t \text { Carrier }}{2 \text { M } 140}$ & ND & ND & ND & ND & ND & ND & ND & ND & ND & ND & ND & 0 & 0 & 0 \\
\hline & $\underset{\text { Carrier }}{1 \text { F }} 160$ & ND & ND & ND & ND & ND & ND & ND & $14 \cdot 4$ & 8.99 & ND & $23 \cdot 3$ & 0 & 0.4 & 0 \\
\hline Regent & $\underset{\text { Carrier }}{2 \underset{F}{ } 160}$ & ND & ND & ND & ND & ND & ND & ND & $5 \cdot 7$ & $16 \cdot 76$ & ND & $22 \cdot 5$ & 0 & $0 \cdot 4$ & 0 \\
\hline $\begin{array}{l}\text { Mean } \\
\text { SD } \\
\text { Regent }\end{array}$ & $\begin{array}{l}\text { Tappers } \\
3 \mathrm{~F}, 1 \mathrm{M}, \\
1 \mathrm{M} 195\end{array}$ & ND & ND & ND & $2 \cdot 76$ & $4 \cdot 12$ & ND & $0 \cdot 26$ & $14 \cdot 29$ & $25 \cdot 69$ & $2 \cdot 8$ & $\begin{array}{l}47 \cdot 1 \\
13 \cdot 6 \\
18 \cdot 2\end{array}$ & $0 \cdot 1$ & $\begin{array}{l}0 \cdot 9 \\
0 \cdot 3 \\
0 \cdot 3\end{array}$ & $0 \cdot 06$ \\
\hline
\end{tabular}

ND $=$ None detected.

Lower limit of detection $10 \mu \mathrm{g} /$ filter.

SD $=$ Standard deviation. 
Table 5 Dermal exposure of rubber tappers. Study 2: normal working procedure (positive results only)

\begin{tabular}{lllll}
\hline Survey No & Tapper and sex & $\begin{array}{l}\text { Sampling duration } \\
(\mathrm{min})\end{array}$ & $\begin{array}{l}\text { Location of exposure } \\
\text { pad }\end{array}$ & $\begin{array}{l}\text { Total potential exposure } \\
(\mathrm{mg} \text { paraquat/h) }\end{array}$ \\
\hline 1 & $8 \mathrm{M}$ & 300 & Left thigh & $0 \cdot 16$ \\
$(\mathrm{mg}$ paraquat/kg/h)
\end{tabular}

Lower limit of detection $6 \mu \mathrm{g} / 25 \mathrm{~cm}^{2}$ for pads and $0.04 \mathrm{mg} / \mathrm{sample}$ for Tubigrip and Stockinette.

Table 6 Dermal exposure of rubber tappers. Study 2: tappers in sprayed areas (positive results only)

\begin{tabular}{|c|c|c|c|c|c|c|}
\hline Survey No & Tapper and sex & $\begin{array}{l}\text { Sampling duration } \\
\text { (mins) }\end{array}$ & $\begin{array}{l}\text { Under clothing } \\
\text { exposure-legs } \\
(\mathrm{mg} \text { paraquat } / \mathrm{h})\end{array}$ & $\begin{array}{l}\text { Location of } \\
\text { exposure pad }\end{array}$ & $\begin{array}{l}\text { Potential exposure } \\
\text { (mg paraquat/h) }\end{array}$ & $\begin{array}{l}\text { Potential dermal } \\
\text { dose } \\
(\mathrm{mg} \text { paraquat } / \mathrm{kg} / \mathrm{h})\end{array}$ \\
\hline 1 & $1 \mathrm{~F}$ & 265 & & Left lower leg & 0.41 & 0.01 \\
\hline 1 & $2 \mathrm{~F}$ & 240 & 0.04 & & 0.04 & $7 \times 10^{-4}$ \\
\hline 1 & $3 \mathrm{M}$ & 265 & & $\begin{array}{l}\text { Left lower leg } \\
\text { Left thigh }\end{array}$ & $\left.\begin{array}{l}1.95 \\
3.01\end{array}\right\} 4.96$ & 0.08 \\
\hline 1 & $5 \mathrm{M}$ & 255 & & $\begin{array}{l}\text { Left lower leg } \\
\text { Left thigh }\end{array}$ & $\left.\begin{array}{l}0.45 \\
0.68\end{array}\right\} 1.13$ & 0.02 \\
\hline 2 & $3 \mathbf{M}$ & 265 & & $\begin{array}{l}\text { Left lower leg } \\
\text { Left thigh }\end{array}$ & $\left.\begin{array}{l}0.95 \\
0.65\end{array}\right\} 1.6$ & 0.03 \\
\hline 2 & $5 \mathrm{M}$ & 265 & & $\begin{array}{l}\text { "V", of neck } \\
\text { Left lower leg } \\
\text { Left thigh }\end{array}$ & $\left.\begin{array}{l}0.01 \\
0.72 \\
1.42\end{array}\right\} 2 \cdot 15$ & 0.04 \\
\hline
\end{tabular}

Lower limit of detection $6 \mu \mathrm{g} / 25 \mathrm{~cm}^{2}$ for pads and $0.04 \mathrm{mg} / \mathrm{sample}$ for Tubigrip and Stockinette.

to $169.8 \mathrm{mg} / \mathrm{h}$. The mean value is equivalent to a dermal dose of $1 \cdot 1 \mathrm{mg} / \mathrm{kg} / \mathrm{h}$. The highest individual total exposure of $169.8 \mathrm{mg} / \mathrm{h}$ is equivalent to 2.8 $\mathrm{mg} / \mathrm{kg} / \mathrm{h}$.

One carrier received direct dermal exposure of $2 \cdot 8$ $\mathrm{mg}$ paraquat/h (table 4 ). This is equivalent to $0 \cdot 1$ $\mathrm{mg} / \mathrm{kg} / \mathrm{h}$, and is higher than the corresponding mean value for spray operators. The mean overall total exposure for carriers was $13.6 \mathrm{mg}$ paraquat/h, equivalent to a dermal dose of $0.3 \mathrm{mg} / \mathrm{kg} / \mathrm{h}$, and the highest individual exposure was $47 \cdot 1 \mathrm{mg}$ paraquat $/ \mathrm{h}$, equivalent to $0.9 \mathrm{mg} / \mathrm{kg} / \mathrm{h}$.

For the single groups of tappers surveyed during the first study, no paraquat was detected on any of the dermal exposure pads, and their exposure was therefore considered to be nil.

Paraquat was detected in only three of 1253 samples analysed from tappers carrying out their normal work (table 5). Two of these samples were located on the left thigh and were close to the limit of determination.

For tappers working in blocks in which spraying of paraquat was taking place, a higher proportion of positive results was obtained (table 6). Most of the paraquat contamination was of the lower legs and thighs. Penetration through clothing was detected

Table 7 Dermal exposure of spray operators. Study 2

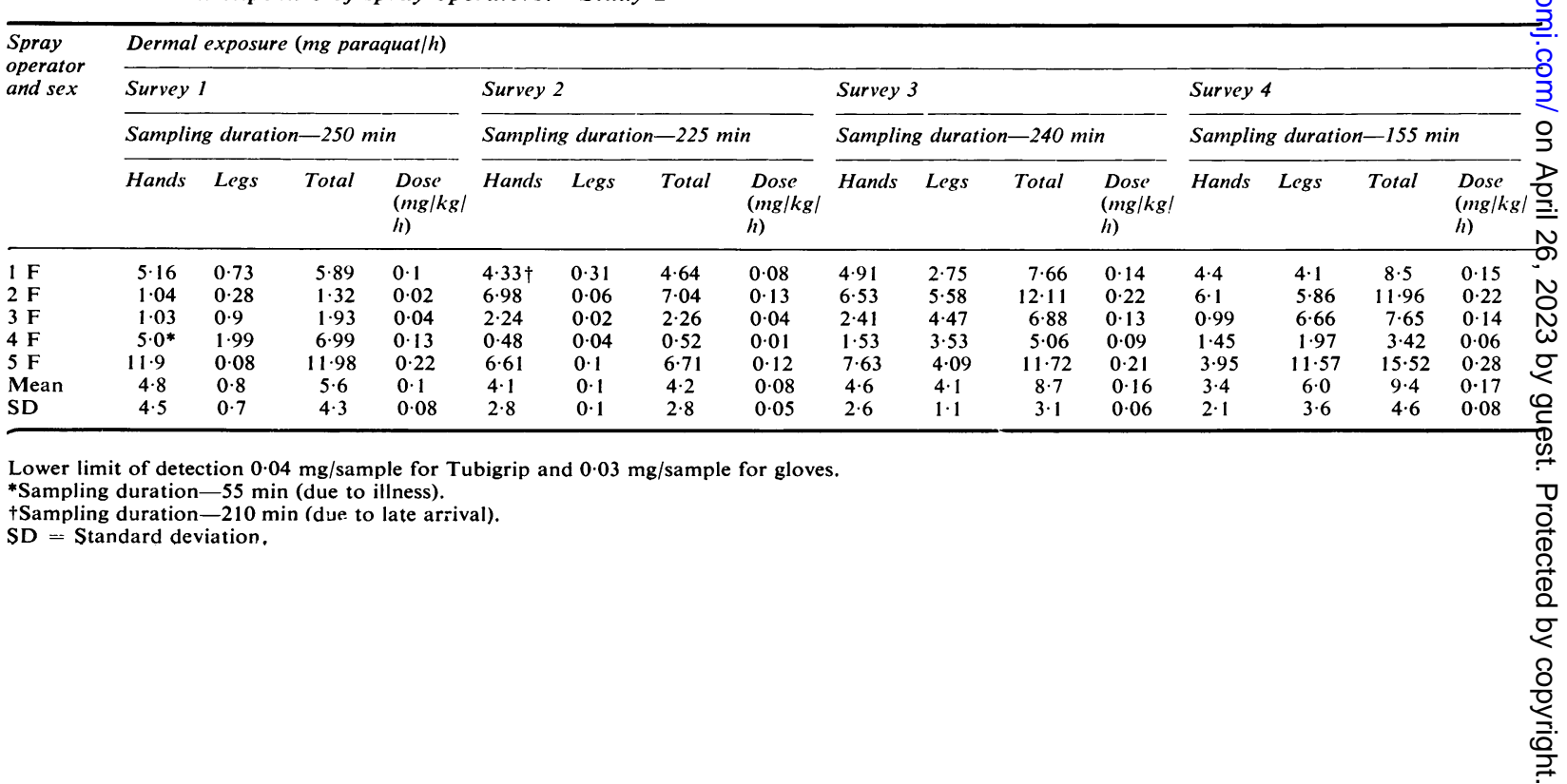


Table 8 Respiratory exposure of spray operators and carriers. Study 1

\begin{tabular}{|c|c|c|c|c|c|}
\hline Dunlop estate & Worker & $\begin{array}{l}\text { Total paraquat per } \\
\text { sampler filter } \\
(\mu \mathrm{g})\end{array}$ & $\begin{array}{l}\text { Sampling duration } \\
\text { (min) }\end{array}$ & $\begin{array}{l}\text { Total volume of air } \\
\text { sampled } \\
(l)\end{array}$ & $\begin{array}{l}\text { Paraquat concentration } \\
\text { in air } \\
\left(\mu \mathrm{g} / \mathrm{m}^{3}\right)\end{array}$ \\
\hline \multicolumn{6}{|l|}{ Sprayers } \\
\hline \multirow[t]{2}{*}{ Regent } & 3 & 0.66 & 60 & 120 & 0.67 \\
\hline & 4 & 0.08 & 135 & 240 & $2 \cdot 75$ \\
\hline Jasin & 3 & 0.28 & 254 & 508 & 0.55 \\
\hline Lallang & 4 & 0.13 & 160 & 320 & 0.41 \\
\hline \multirow[t]{2}{*}{ Gomali } & 3 & 0.41 & 140 & 280 & 1.46 \\
\hline & 4 & $0 \cdot 16$ & 140 & 280 & 0.57 \\
\hline \multirow[t]{2}{*}{ Segamat } & 1 & 0.28 & 160 & 320 & 0.88 \\
\hline & 2 & 0.27 & 160 & 320 & 0.84 \\
\hline Regent & $\overline{1}$ & 0.28 & 225 & 450 & 0.62 \\
\hline Mean & & & & & 0.97 \\
\hline SD & & & & & 0.73 \\
\hline \multicolumn{6}{|l|}{ Carriers } \\
\hline Regent & 1 & ND & 60 & 120 & ND \\
\hline Jasin & 1 & $0 \cdot 28$ & 140 & 280 & $1 \cdot 0$ \\
\hline \multicolumn{6}{|l|}{ Lallang } \\
\hline Gomali & 2 & ND & 140 & 280 & ND \\
\hline Segamat & 1 & ND & 160 & 320 & ND \\
\hline Regent & 1 & 0.09 & 225 & 450 & $0 \cdot 20$ \\
\hline Mean & & & & & $0 \cdot 24$ \\
\hline SD & & & & & 0.43 \\
\hline
\end{tabular}

ND $=$ None detected.

Lower limit of detection $0.03 \mu \mathrm{g} /$ filter.

SD $=$ Standard deviation.

Table 9 Respiratory exposure of spray operators. Study 2

\begin{tabular}{|c|c|c|c|c|c|c|}
\hline Survey & $\begin{array}{l}\text { Spray operator } \\
(5 \text { women })\end{array}$ & $\begin{array}{l}\text { Total paraquat } \\
\text { sampled } \\
(\mu g \mid \text { filter })\end{array}$ & $\begin{array}{l}\text { Sampling duration } \\
\text { (min) }\end{array}$ & $\begin{array}{l}\text { Total volume of air } \\
\text { sampled } \\
\text { (l) }\end{array}$ & $\begin{array}{l}\text { Paraqu } \\
\text { air } \\
\left(\mu g / m^{3}\right)\end{array}$ & t concentration in \\
\hline & 1 & 0.15 & 250 & 500 & & $0 \cdot 3$ \\
\hline & 2 & 0.63 & 250 & 500 & & $1 \cdot 26$ \\
\hline \multirow[t]{7}{*}{1} & 3 & 0.04 & 250 & 500 & & 0.08 \\
\hline & 4 & 0.05 & 55 & 110 & & 0.45 \\
\hline & 5 & $46 \cdot 56$ & 250 & 500 & & $93 \cdot 12$ \\
\hline & & & & & Mean & 19.04 \\
\hline & & & & & SD & $41 \cdot 41$ \\
\hline & 1 & $0 \cdot 10$ & 210 & 420 & & 0.23 \\
\hline & 2 & ND & 225 & 450 & & ND \\
\hline \multirow[t]{7}{*}{2} & 3 & 0.49 & 225 & 450 & & 1.0 \\
\hline & 4 & 0.05 & 225 & 450 & & $0 \cdot 11$ \\
\hline & 5 & 0.03 & 225 & 450 & & 0.07 \\
\hline & & & & & Mean & $0 \cdot 3$ \\
\hline & & & & & SD & 0.5 \\
\hline & 1 & $0 \cdot 19$ & 240 & 480 & & 0.4 \\
\hline & 2 & 0.04 & 240 & 480 & & 0.08 \\
\hline \multirow[t]{7}{*}{3} & 3 & 0.08 & 240 & 480 & & $0 \cdot 17$ \\
\hline & 4 & 0.03 & 240 & 480 & & 0.06 \\
\hline & 5 & 0.04 & 240 & 480 & & 0.08 \\
\hline & & & & & Mean & 0.2 \\
\hline & & & & & SD & $0 \cdot 1$ \\
\hline & 1 & 0.04 & 155 & 310 & & $0 \cdot 13$ \\
\hline & 2 & ND & 155 & 310 & & ND \\
\hline \multirow{7}{*}{4} & 3 & 0.03 & 155 & 387 & & 0.08 \\
\hline & 4 & 0.03 & 155 & 310 & & $0 \cdot 1$ \\
\hline & 5 & 0.02 & 155 & 310 & & 0.07 \\
\hline & & & & & Mean & 0.07 \\
\hline & & & & & SD & 0.05 \\
\hline & & & & Overa & 1 mean & $\begin{array}{r}4.89 \\
\end{array}$ \\
\hline & & & & & SD & $20 \cdot 77$ \\
\hline
\end{tabular}

ND $=$ None detected.

Lower limit of detection $0.02 \mu \mathrm{g} /$ filter

SD $=$ Standard deviation.

for only one individual. Interestingly, the exposure pads located on the other leg of this worker were not contaminated with paraquat.
Penetration through trouser material was determined for each spray operator in each of the four surveys of study 2 (table 7). A mean exposure of $2 \cdot 8$ 
Table 10 Respiratory exposure of tappers. Study 2

\begin{tabular}{|c|c|c|c|c|}
\hline Tapper & $\begin{array}{l}\text { Total paraquat sampled } \\
(\mu g / \text { filter })\end{array}$ & $\begin{array}{l}\text { Sampling duration } \\
\text { (min) }\end{array}$ & $\begin{array}{l}\text { Total volume of air } \\
\text { sampled } \\
\text { (l) }\end{array}$ & $\begin{array}{l}\text { Paraquat concentration in } \\
\text { air } \\
\left(\mu \mathrm{g} / \mathrm{m}^{3}\right)\end{array}$ \\
\hline $\begin{array}{l}1 \\
2 \\
3 \\
4 \\
5\end{array}$ & $\begin{array}{l}\text { ND } \\
\text { ND } \\
\text { ND } \\
\text { ND } \\
\text { Pump failure }\end{array}$ & $\begin{array}{r}265 \\
265 \\
265 \\
265 \\
0\end{array}$ & $\begin{array}{r}530 \\
530 \\
530 \\
530 \\
0\end{array}$ & $\begin{array}{l}\text { ND } \\
\text { ND } \\
\text { ND } \\
\text { ND } \\
-\end{array}$ \\
\hline
\end{tabular}

ND $=$ None detected.

Lower limit of detection $0.02 \mu \mathrm{g}$ /filter.

Table 11 Paraquat residues in urine. Study 1

\begin{tabular}{|c|c|c|c|c|c|}
\hline \multirow[t]{3}{*}{ Workers } & \multicolumn{5}{|c|}{ Paraquat residues $(\mathrm{mg} / \mathrm{l})$} \\
\hline & \multicolumn{5}{|c|}{ Dunlop Estate } \\
\hline & Regent & Jasin Lallang & Gomali & Segamat & Regent \\
\hline \multicolumn{6}{|c|}{ Spray operators } \\
\hline 1 & $<0.05$ & 0.69 & 0.08 & $<0.05$ & 0.05 \\
\hline 2 & $<0.05$ & 0.76 & 0.19 & $<0.05$ & $<0.05$ \\
\hline 4 & 0.05 & $<0.05$ & $<0.05$ & $<0.05$ & - \\
\hline \multicolumn{6}{|l|}{ Carriers } \\
\hline 1 & $<0.05$ & 0.07 & $<0.05$ & $<0.05$ & $<0.05$ \\
\hline 2 & - & - & $<0.05$ & $<0.05$ & - \\
\hline \multicolumn{6}{|l|}{ Tappers } \\
\hline 1 & $<0.05$ & & & & \\
\hline 2 & $<0.05$ & & & & \\
\hline 3 & $<0.05$ & & & & \\
\hline 4 & $<0.05$ & & & & \\
\hline
\end{tabular}

Lower limit of detection $0.05 \mu \mathrm{g} / \mathrm{ml}$.

$(0 \cdot 02-11 \cdot 6) \mathrm{mg}$ paraquat $/ \mathrm{h}$ was calculated for the legs. The dermal exposure of the hands exceeded that of the legs in most operators, and mean exposure was calculated to be $4.2(0.5-11.9) \mathrm{mg}$ paraquat $/ \mathrm{h}$. The overall, mean contribution of hand and leg exposure to total exposure was calculated to be $7 \cdot 0(0 \cdot 5-15 \cdot 5)$ $\mathrm{mg}$ paraquat $/ \mathrm{h}$, equivalent to a dermal dose contribution of $0.13(0.009-0 \cdot 3) \mathrm{mg} / \mathrm{kg} / \mathrm{h}$.

\section{RESPIRATORY EXPOSURE}

From the first study, the mean paraquat concentration in air was determined to be $0.97 \mu \mathrm{g}$ paraquat $/ \mathrm{m}^{3}$ for spray operators (table 8). The mean concentration from the second study was $4.9 \mu \mathrm{g}$ paraquat $/ \mathrm{m}^{3}$ (table 9). This mean value was biased by one very high value of $93.1 \mu \mathrm{g} / \mathrm{m}^{3}$, which is considered to be due to accidental contamination of the sampler filter by contaminated hands or misdirected spray. If this is not included in the calculation of mean concentration a value of $0.25 \mu \mathrm{g}$ paraquat $/ \mathrm{m}^{3}$ is obtained, which is of the same order as that obtained for spray operators in the first study.

The mean respiratory exposure of carriers was 0.24 $\mu \mathrm{g}$ paraquat $/ \mathrm{m}^{3}$ (table 8 ). For three of the five carriers monitored, no paraquat was detected in their breathing zones. For the group of tappers monitored in a block being sprayed with a paraquat containing herbicide formulation, no paraquat was detected in their breathing zones (table 10).

\section{URINE ANALYSIS}

Paraquat residues were detected in the urine of nine of 19 spray operators, and one of seven carriers (table 11). Two of the four female spray operators on Jasin Lallang Estate excreted more paraquat than any of the male operators despite a relatively lower potential exposure (table 3 ).

"PERCENTAGE TOXIC DOSES", (Study 1 only) The mean "percentage dose" for spray operators is $0.05 \%$ an hour, or $0.3 \%$ a working day (table 3 ). The highest individual percentage dose is $0.25 \%$ an hour or $1.5 \%$ a day. One carrier received a percentage dose of $0.06 \%$ an hour, or $0.36 \%$ a working day (table 4). These calculations of percentage toxic dose are based on exposed body part data, and not total potential exposure. 


\section{Discussion}

The dermal exposure data obtained during the first study may be interpreted in two ways. The first takes into consideration only those body parts not covered by clothing, and a necessary assumption is made that the clothing worn afforded complete protection to the underlying skin. The second method of interpretation takes into consideration the contamination of clothing in addition to the direct exposure of unclothed body parts, and is based on the assumption that a proportion of the paraquat on clothing must have penetrated to the underlying skin. For the purposes of calculation, "worst case" exposure has been assumed-that is, $100 \%$ penetration. The estimate is, therefore, one of maximum potential exposure.

Consideration of the dermal exposure data of this first study indicates that the mean total exposure for spray operators was influenced by a few, very high potential exposures of the legs. These resulted from the accidental self-spraying and spillage of the dilute spray formulation that was seen. Actual dermal exposure is considered to be between the two calculated extremes of $2.2 \mathrm{mg}$ (unclothed) and 66.1 $\mathrm{mg}$ (clothed) paraquat/h depending on the degree of penetration of clothing by paraquat. Although few directly comparable studies have been reported, Staiff et $a l^{2}$ carried out similar studies on field tractor applicators and garden pressurised hand spray applicators. Using a method of interpretation similar to the first method described above, they obtained mean dermal exposure of $0.4(0.01-3.4) \mathrm{mg}$ and $0.29(0.01-0.57) \mathrm{mg}$ paraquat/h respectively. These may be compared to the $2 \cdot 2(0-12.4) \mathrm{mg}$ paraquat $/ \mathrm{h}$ in this study. The highest dermalrespiratory exposure seen by Staiff et al, ${ }^{2}$ roughly 3.4 $\mathrm{mg} / \mathrm{h}$, represented only $0.06 \%$ of a toxic dose per hour of exposure. The highest dermal exposure of $12.4 \mathrm{mg} / \mathrm{h}$ during study 1 represents $0.25 \%$ of a toxic dose an hour. Hogarty, ${ }^{3}$ in a study of knapsack spray operator exposure to paraquat, reported only two paraquat-positive gauze patches in a total of 87 analyses. The gauzes were located on the neck of one operator and the wrist of another, and both were close to the limit of detection. Hogarty concluded that there was little likelihood of dermal contamination when protective clothing is worn.

When actual dermal exposure of the legs was measured, using Tubigrip bandages placed beneath clothing from the ankle to the thigh of each spray operator in the second study, penetration of paraquat was detected during each of the four surveys (table 7). If the overall mean leg exposure of $2.8 \mathrm{mg}$ paraquat/h is related to the mean paraquat contamination of leg exposure pads from the first study
(58.8 $\mathrm{mg}$ paraquat $/ \mathrm{h})$, it is possible to obtain an estimate of the "penetrability ratio", which indicates about $5 \%$ penetration through clothing by paraquat. If the crop type and weed height are considered, the lowest leg exposure occurred during spot-spraying of relatively shorter weeds in cocoa (survey 2 ). The highest leg exposure occurred during survey 4 , in which there was a combination of spot-spraying in cocoa and strip-spraying in rubber. The former took place on flat terrain, whereas the latter took place mainly on sloped terrain. Thus there appears to be a difference in the degree of leg exposure according to the type of ground spraying carried out.

The overall mean exposure of the hands of spray operators from the second study of $4.2 \mathrm{mg}$ paraquat/h, when compared with the mean exposure of $1.2 \mathrm{mg}$ paraquat/h from the first study, is a more realistic assessment as the latter used forearm exposure data extrapolated to hand exposure. In three of the four surveys of spray operator exposure in the second study mean hand exposure exceeded mean leg exposure, and in two of these by a considerable margin. This incidence of hand exposure is to be expected when work practices are considered. The operators often handled the spray nozzles in an attempt to align them correctly or to unblock them. One operator was even observed to wash her hands in the spray tank of diluted herbicide formulation after lubricating the knapsack sprayer mechanism with oil. It is readily apparent that certain spray operators were less hygienic in their work practices than others. Consideration of the data (table 7) shows that operator number 5 received consistently higher dermal exposure relative to that of the remaining four operators. This was primarily the result of contamination of the hands, as the pattern of leg exposure was similar for all operators.

Overall, the dermal exposure of spray operators to paraquat did not represent a toxicological hazard, and this conclusion is supported by the epidemiological survey carried out by Howard et al, ${ }^{4}$ which showed that there were no quantifiable harmful effects on health attributable to paraquat.

The major source of dermal exposure of carriers (table 4) was contamination when walking through recently sprayed vegetation and accidental spillage during carrying and loading, and is insufficient to cause concern.

The dermal exposure data for tappers (table 4) indicate that no measurable exposure to paraquat occurred. The block in which the tappers were working had been sprayed with paraquat eight days previously, and residual paraquat was not expected to be present. Data from the 18 surveys of tapper dermal exposure conducted during the second study showed that three tappers were exposed to paraquat 
on three separate occasions. The tapper working population was thus deemed to be an exposed group and as such was not included in the epidemiology study on health being carried out simultaneously (Howard $e t a l^{4}$ ), despite the fact that their exposure to paraquat was infrequent and negligible.

The two surveys to determine tapper exposure in simultaneously sprayed blocks showed that leg contamination can occur while walking through recently sprayed vegetation. In only one case was penetration through clothing to Tubigrip or Stockinette determined, giving a dermal dose of $7 \times 10^{-4} \mathrm{mg}$ paraquat $/ \mathrm{kg} / \mathrm{h}$, which may be considered negligible.

In relation to the interpretation of the respiratory exposure data, the following information is of direct relevance. Knapsack sprayers with fan, cone, and red polijet nozzles are said to produce droplet size distributions with volume mean diameters in the range $200-400 \mu \mathrm{m} .{ }^{11}$ The droplet size distributions of standard knapsack spray jets of the swirljet and polijet type have been characterised by Hogarty, ${ }^{3}$ who found that the respirable fraction generated by these spray systems was in the order of $0.001 \%$ of the total spray volume. He also showed that a spray operator might be exposed to, on average, $50 \%$ respirable droplets, as only the smaller particles produced by the sprayer will tend to reach the breathing zone. The respirable fraction, therefore, constituted a higher percentage of total spray reaching the breathing zone. It was emphasised that the total amounts were a very minute fraction of the total spray volume. Droplets smaller than $10 \mu \mathrm{m}$ could be produced by evaporation, but this is unlikely in the tropical climate of Malaysia with its very high humidity. Probably, therefore, the respirable component of the total spray emitted by the spray systems used in these studies was similarly minute.

The American Conference of Governmental Industrial Hygienists ${ }^{12}$ have published a threshold limit value-time weighted average (TLV) for respirable paraquat of $100 \mu \mathrm{g} / \mathrm{m}^{3}$, and a comparison is drawn between the respiratory exposure from these studies and this TLV, while recognising that the latter may not be strictly appropriate to the agricultural workplace. The mean concentration of total airborne paraquat in the breathing zones of spray operators in the first study $\left(0.97(0.41-2.75) \mu \mathrm{g} / \mathrm{m}^{3}\right.$ (table 8)) was $1 \%$ of the TLV for respirable paraquat. From the second study, if the abnormally high value is excluded, mean exposure $\left(0.25(0-1 \cdot 26) \mu \mathrm{g} / \mathrm{m}^{3}\right)$ represents only $0.25 \%$ of the TLV. From Hogarty's study, ${ }^{3}$ the respirable paraquat concentrations would have been $50 \%$ of these total airborne paraquat concentrations.

A mean concentration of $0.24(0-1 \cdot 0) \mu \mathrm{g} / \mathrm{m}^{3}$ total airborne paraquat was determined for carriers (table 8 ). This represents $0.24 \%$ of the TLV. No paraquat was detected in the breathing zones of tappers working in blocks being sprayed with a paraquat containing herbicide formulation. The respiratory exposure data from these studies indicate that there is unlikely to be a respiratory toxicity hazard to any of the three groups of workers during knapsack-spraying of paraquat.

The extent of systemic absorption was estimated by measuring paraquat in urine samples taken at the end of a spraying session, from operators who sprayed paraquat regularly. The highest concentrations $(0.69$ and $0.76 \mathrm{mg} / \mathrm{l})$ were found in female spray operators on Jasin Lallang Estate. This may reflect the greater risks of accidental contamination when obtaining urine samples from women. Swan ${ }^{1}$ determined the urinary excretion pattern of paraquat for Malaysian spray operators. Over a 12-week period the highest concentration found was 0.32 $\mathrm{mg} / \mathrm{l}$, with most under $0 \cdot 1 \mathrm{mg} / \mathrm{l}$. In later trials, over a period of 13-14 weeks, the highest concentration found was $0.15 \mathrm{mg} / \mathrm{l}$. Therefore, the urinary paraquat concentrations determined in study 1 are of the same order as those determined by Swan. ${ }^{1}$

Since the permeability of paraquat (a charged moiety) through intact human skin is extremely slow compared with many other groups of pesticides, such as organophosphate insecticides, the concentration of paraquat in urine measured after a spraying session would be unlikely to reflect exposure during that period. A more realistic assessment of paraquat absorption could have been made by collecting the total volume of urine voided during the first 24 hours after cessation of spraying. This procedure, however, would have been difficult to achieve without interfering with normal work practices.

\section{Conclusions}

These studies show that of the three groups of workers surveyed, spray operators are the most exposed group. Tappers, while exposed to extremely low levels of paraquat, cannot be considered an unexposed group.

A comparison of the published data on dermal and respiratory exposure to paraquat with the calculated exposures from these studies shows that there should be no toxic hazard to the three groups of workers as a consequence of its use.

We acknowledge the invaluable help and cooperation given by $\mathrm{Dr} N \mathrm{~N}$ Sabapathy, the estate managers, and hospital staff of Dunlop Estates Bhd. We also thank $\mathrm{Mr} \mathrm{N}$ Smith and other Imperial 
Chemical Industries (Malaysia) staff who gave valuable help in ensuring customs release of equipment. Administrative and technical support were ably provided by Messrs Lim Jit Kim and Vejai Debb, respectively. The advice and help of Dr A K Seth, Dr M S Rose, and Dr S E Jaggers of ICI Ltd and $\mathrm{Dr} \mathbf{J}$ K Howard of Chemical Industries Association are also gratefully acknowledged.

\section{References}

${ }^{1}$ Swan AAB. Exposure of spray operators to paraquat. $\mathrm{Br} J$ Ind Med 1969;26:322-9.

${ }^{2}$ Staiff DC, Comer SW, Armstrong JJ, Wolfe HR. Exposure to the herbicide paraquat. Bull Environ Contam Toxicol 1975;14:334-40.

${ }^{3}$ Hogarty C. Exposure of spray operators to paraquat. Dublin: Dublin Institute for Industrial Research and Standards, 1975.

${ }^{4}$ Howard JK, Sabapathy NN, Whitehead PA. A study of the health of Malaysian plantation workers occu- pationally exposed to paraquat. Br J Ind Med $1981 ; 38$ : 110-6.

${ }^{5}$ World Health Organisation. Standard protocol: survey of exposure to organophosphorus pesticides in agriculture. Geneva: WHO, 1975. (VBC/75.9.)

- Calderbank A, Yuen SH. An ion-exchange method for determining paraquat residues in food crops. Analyst 1965;90:99-106.

${ }^{7}$ Levitt T. Determination of paraquat in clinical practice using radioimmunoassay. Proc Analyt Div Chem Soc 1979 Feb:72-6.

${ }^{8}$ Diem K, Lentner C, eds. Scientific tables. 7th ed. Basle: Ciba-Geigy Ltd, 1972.

${ }^{9}$ Durham WF, Wolfe HR. Measurement of the exposure of workers to pesticides. Bull WHO 1962;26:75-91.

${ }^{10}$ Chester G. Toxicological comparison of new wetter systems for paraquat formulations. ICI, 1979. (ICI Internal Report No CTL/P/448.)

11 Arnold AC. Droplet spectra for the 20 most commonly used hydraulic nozzles. British Crop Protection Council, 1979. (Control testing scheme report.)

12 American Conference of Governmental Industrial Hygienists. Threshold limit values for chemical substances and physical agents in the workroom environment with intended changes for 1980 . 